\title{
A suspended migration of humpback whales Megaptera novaeangliae on the west coast of South Africa
}

\author{
Peter B. Best*', Keiko Sekiguchi*, Ken P. Findlay * \\ Mammal Research Institute, University of Pretoria, Pretoria, 0002 South Africa
}

\begin{abstract}
Between 5 October and 19 November 1993, 62 sightings of 155 humpback whales were made from the lighthouse at Cape Columbine, South Africa, in 3 episodes about $9 \mathrm{~d}$ apart. For 59 groups tracked by theodolite, the average distance of fshore peaked at 2 to $2.5 \mathrm{~km}$. Independent information on offshore distribution was obtained from $1112 \mathrm{~km}$ searched by a ski-boat in the vicinity of Cape Columbine, from which the proportions of humpback whale groups in 2 strata ( 0 to 5 and $>5 \mathrm{~km}$ ) from the shore as seen from the lighthouse did not differ from those expected from the boat data. Net directions of movement for 51 groups were distributed equally to all 4 quadrants of the compass, and those groups showing a concerted directionality of movement were headed equally to the north and to the south. Of the same 51 groups, $70 \%$ travelled at net speeds of less than $1.5 \mathrm{~km} \mathrm{~h}^{-1}$. Migratory indices for individual groups (average speed/net speed) ranged as high as 82 , and those with the lowest indices (corresponding to those most likely to be migrating) were distributed equally between northerly and southerly directions. Individual identification photographs taken of 27 humpback whales over $20 \mathrm{~d}$ revealed only 10 individuals, 5 of which were resighted on more than 1 occasion and up to 20 d apart. Apparent feeding behaviour by humpback whales was seen on 10 occasions over $38 \mathrm{~d}$, and the production of reddish particulate faeces indicative of recent feeding was seen on 7 occasions, at a defecation rate of 0.22 whale - $^{-1}$ Faecal samples collected contained euphausiid remains (possibly Euphausia lucens) on 2 occasions and amphipods on another. Overall the data indicated that the southward migration of humpback whales expected at this time of year on the west coast of South Africa had been suspended, probably in response to locally abundant prey.
\end{abstract}

KEY WORDS: Humpback whale Migration Feeding South Africa

\section{INTRODUCTION}

It is commonly accepted that humpback whales in the southern hemisphere undertake seasonal migrations between Antarctic feeding grounds in summer and tropical or temperate breeding grounds in winter (Mathews 1938), during which they characteristically approach or follow the coasts of continents from headland to headland, depending on the conformation of the coast (Dawbin 1966, Bryden 1985). One such migration path supposedly takes humpback whales

\footnotetext{
- Postal address: Whale Unit, c/o South African Museum PO Box 61, Cape Town, South Africa
}

past the west coast of South Africa in autumn en route to breeding grounds off Angola, the Congo or Gabon, and another past the east coast of South Africa en route to Mozambique, both returning in spring en route to the Antarctic (Olsen 1914). The characteristics of the east coast migrations have been studied at Cape Vidal in northern Natal from 1988 to 1991 (Findlay 1994), but there has been essentially no new information on west coast migrations since the publication of Matthews (1938), although there is some indication from the level of recent incidental sightings that the population may be increasing (Best 1993).

This paper describes the characteristics of the southern migration of humpback whales on the west coast of South Africa during October and November 1993. It 
was decided to concentrate on the southern rather than the northern migration, because weather conditions were expected to be better, whales might reside longer in the area because of the conformation of the coast, and many females might be accompanied by calvesof-the-year (giving the potential for studies of calving frequency). In the event, although humpback whales were frequently seen, they did not appear to be actively migrating through the area.

\section{MATERIALS AND METHODS}

Research was based at Cape Columbine $\left(32^{\circ} 50^{\prime} \mathrm{S}\right.$, $17^{\circ} 51^{\prime}$ E), the westernmost headland in South Africa south of $31^{\circ} 30^{\prime} \mathrm{S}$ (Fig. 1), and only $15 \mathrm{n}$ miles north of the site of the Donkergat whaling station in Saldanha Bay. The choicc of a period within the southern migration for this pilot project was based on data presented by Olsen (1914), showing catches at the Donkergat whaling station by $10 \mathrm{~d}$ period during the 1911 and 1912 seasons (when humpback whales were still a principal target of the fishery). These data indicated a peak in the last $10 \mathrm{~d}$ of October (Fig. 2), so a survey period from 5 October to 19 November 1993 was selected.

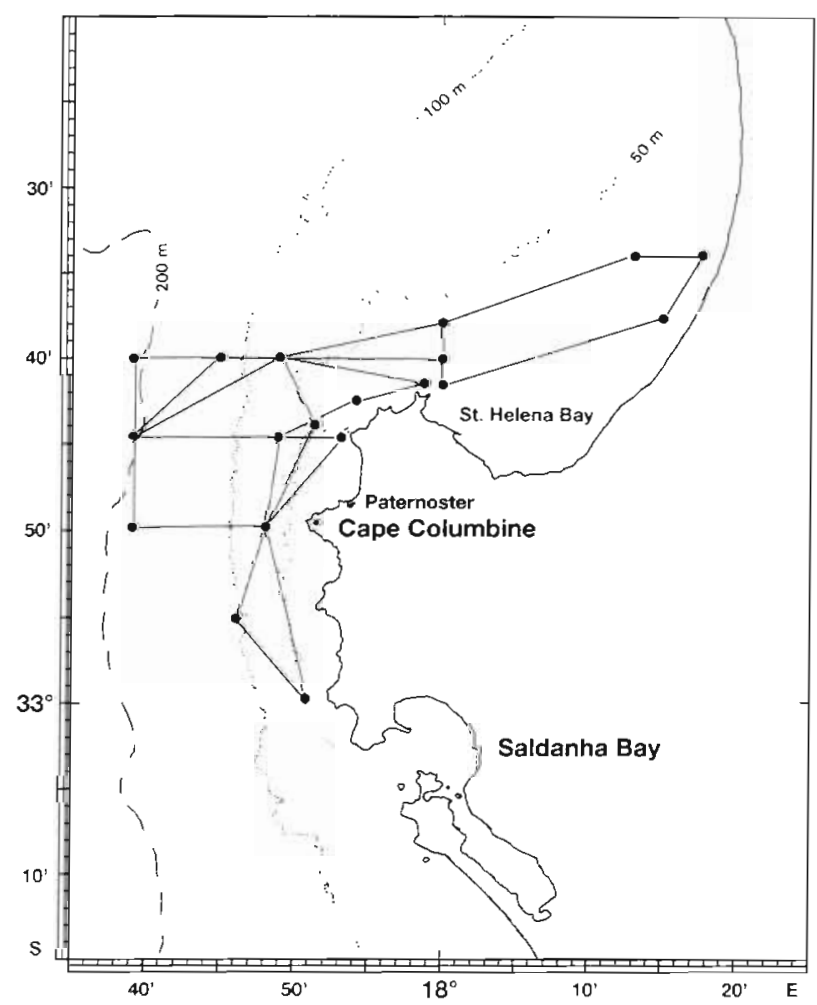

Fig. 1. West coast of South Africa, showing situation of Cape Columbine and the transect legs covered by the 'Ecklonia' *Position of the iighthouse

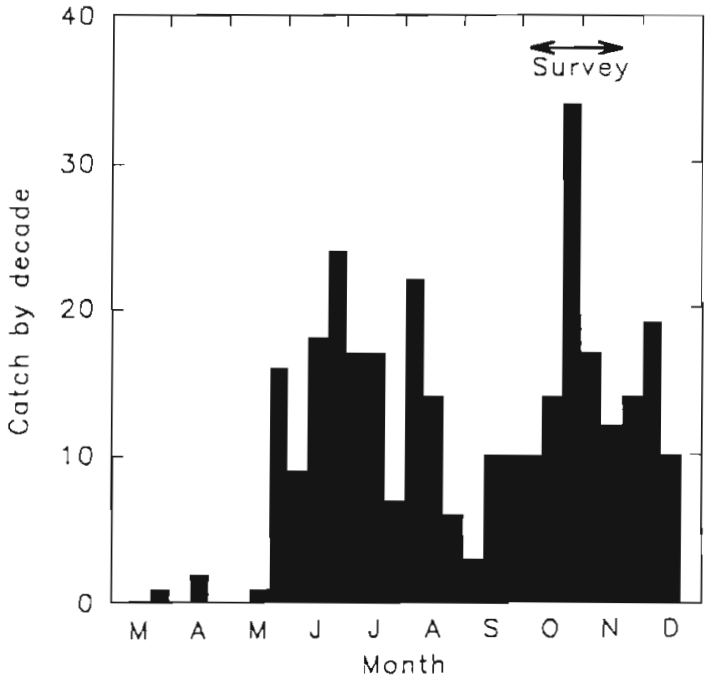

Fig. 2. Megaptera novaeangliae. The catch of humpback whales landed at the Donkergat whaling station, Saldanha Bay, by $10 \mathrm{~d}$ period during 1911 and 1912 combined (from Olsen 1914)

A look-out for whales was kept from the balcony of the lighthouse at Cape Columbine from 07:00 to 19:00 h (or from about $1 \mathrm{~h}$ after sunrise to sunset) every day, weather permitting, for a total of $424 \mathrm{~h}, 7$ min of watch. Teams of 2 (or sometimes 3 ) observers were on watch for 2 (or sometimes 3 ) h at a time, before being relieved by an alternate team. Searching was carried out mainly with Minolta $7 \times 35$ wide-angle binoculars. Every third day one of the teams was allocated to boat work (see below).

Groups of whales seen were tracked using a Wild T1 theodolite (with automatic vertical index), mounted on a specially constructed bracket on the wall of the lighthouse balcony. Through data on the height of the lighthouse provided by Trigonometrical Survey, and measurements of the position of the theodolite relative to the lighthouse structure, the focal plane of the theodolite could be established as $78.8 \mathrm{~m}$ above mean sea level. A conspicuous rock on the foreshore ('Needle' Rock) was used each morning at the start of observations as a reference point for theodolite readings in the horizontal plane; the angle between the reference point and the baseline of the orthogonal grid system was established from an aerial survey photograph of the area

Vertical and horizontal angles at each theodolite reading were measured to the nearest $3 \mathrm{~s}$, and the time recorded to the nearest second. A programme was written in BASIC to convert the vertical angles to distances of the whales from the observer, taking into account the curvature of the earth and an average refraction value for tropical/temperate latitudes (Kah- 
men \& Faig 1988). In conjunction with the bearings obtained from the horizontal angles, these distances enabled the position of the whale relative to the observer to be 'fixed'. The same programme then calculated the linear distance and bearing between successive fixes and, given the time interval, the speed of movement. The distance of each 'fix' from the nearest section of coastline was also calculated, using a digitised version of the coastline. After the final fix had been established, the programme calculated, for each sighting:

(1) the average speed (the sum of the distances travelled between each fix divided by the time interval between the first and last fix);

(2) the average bearing (as calculated for circular distributions in Zar 1984);

(3) the average distance offshore (the unweighted average of the distances offshore recorded at each fix);

(4) the net bearing (that between first and last fixes only); and

(5) the net speed (taken as the linear distance travelled between first and last fixes divided by the time interval between the same fixes)

If a group was seen to split, or join up with another group during tracking, then for the purposes of analysis the smallest sub-groups were treated as separate sightings, e.g. if a group of 4 seen at 08:00 h split into 2 groups of 2 at 10:00 h before being lost at 12:00 h, 2 complete tracks would be analysed for each pair from 08:00 to $12: 00 \mathrm{~h}$.

'Approximate' fixes (those made on the slick left by the whale, for instance, or those made as a rough guide to the position when first sighted) were omitted from all calculations.

Weather conditions were recorded at hourly intervals, commencing half an hour after watch began, and included wind direction and speed, cloud cover (over the sea), swell height and a sightability index on a scale of 1 (very poor) to 5 (excellent), which was intended as a subjective impression of how good the overall conditions were for whale-spotting. Visibility on the midiline $\left(270^{\circ}\right)$ was measured through the theodolite, using the vertical reading where waves became indistinct.

Record was also kept of whenever a change in the search activity of the observers occurred, e.g. from searching to tracking whales, or from tracking whales to searching, from searching to recording weather conditions, or when searching was suspended for poor visibility, or at the end of the day.

In order to obtain independent information on the offshore distribution of humpback whales, and to take identification photographs and skin biopsies of individual whales, the $8 \mathrm{~m}$ skiboat 'Ecklonia' was chartered between 12 October and 10 November. It was either based at St Helena Bay harbour, or left at a mooring in Paternoster Bay, just north of the lighthouse. A separate team of 2 observers was allocated each day to accompany the 'Ecklonia', and communication with the observers on the lighthouse was maintained by $29 \mathrm{mHz}$ radio. A specially constructed elevated chair placed one observer about $3 \mathrm{~m}$ above sea level. If weather conditions permitted, the 'Ecklonia' began each day with a series of transects to previously determined waypoints, designed to examine the offshore-onshore and coast-wise distribution of whales (Fig. 1). Initially these transects were run entirely independently of the lighthouse sightings, but with the limited boat-time available it soon became clear that a more efficient use of the boat was to inform the 'Ecklonia' of any sightings that were not on the transect that it was searching, so that an interception could be made as soon as the transect had been completed. Navigation was based on a portable Magellan GPS.

Individual identification photographs of the tail flukes and dorsal fin of humpback whales encountered by boat were taken with a Minolta X500 $35 \mathrm{~mm}$ camera plus 100 to $300 \mathrm{~mm}$ lens, using $400 \mathrm{ASA}$ black-andwhite film.

Migration parameters for humpback whales on the east coast of South Africa, based on data collected at Cape Vidal (28 $07^{\prime} \mathrm{S}, 32^{\circ} 33^{\prime} \mathrm{E}$ ) in 1990 , have been included for comparative purposes. Essentially the same methodologies were used as in this paper, groups of whales being tracked by $\mathrm{T} 1$ theodolite from a tower on a coastal sand dune $61.5 \mathrm{~m}$ above sea level and about $100 \mathrm{~m}$ back from the shore. The same algorithm was used to obtain swimming speeds and directions from the theodolite data (Findlay 1994). Because the whales were actively migrating through the area, however, they were generally tracked for shorter periods than at Cape Columbine.

\section{RESULTS}

\section{Temporal and spatial distribution of sightings}

In total, 195 sightings of 356 whales were made (Table 1). Of these, 62 sightings were of 155 humpback whales.

The number of hours spent on watch each day (where this includes periods of tracking and weather recording) is shown in Fig. 3. Only $4 \mathrm{~d}$ were completely (or almost completely) lost to poor weather conditions; in these cases, and where less than $5 \mathrm{~h}$ of watch were possible, whale densities (as number of groups seen per hour) were calculated from the average of those on preceding and subsequent days. 
Table 1. Whales seen from the lighthouse, Cape Columbine. 5 October to 19 November 1993

\begin{tabular}{|lcr|}
\hline Species & Groups & Whales \\
\hline Humpback whale & & \\
$\quad$ Megaptera novaeangliae & 62 & 155 \\
Southern right whale & & \\
$\quad$ Eubalaena australis & 68 & 117 \\
Fin whale Balaenoptera physalus & 3 & 3 \\
Minke whale B. acutorostrata & 5 & 8 \\
Unidentified whale & 42 & 57 \\
Unidentified balaenopterid & 2 & 2 \\
Like-humpback & 1 & 1 \\
Like-right & 8 & 8 \\
Like-minke & 4 & 5 \\
Total & 195 & 356 \\
\hline
\end{tabular}

Humpback whales seemed to occur in 3 episodes, with absences of $9 \mathrm{~d}$ intervening (Fig. 3). The first episode (from 6 to 17 October) included the highest daily densities, and $58 \%$ of groups seen during the survey were encountered during this period (compared to $14.5 \%$ and $27.5 \%$ in the second and third episodes respectively).

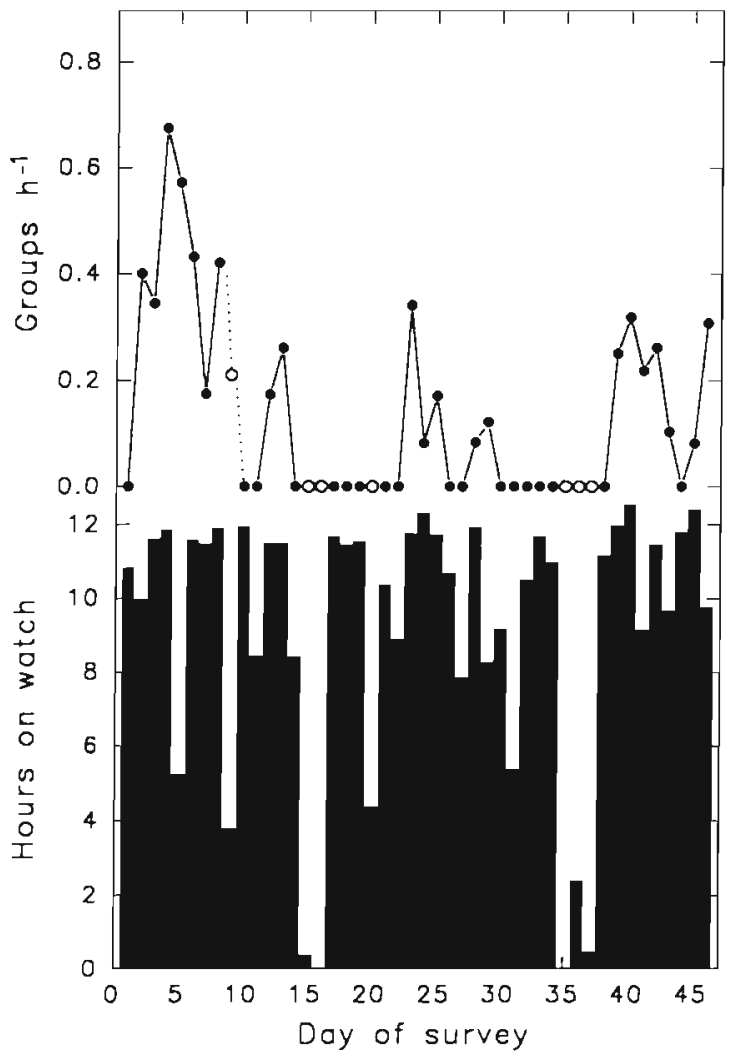

Fig. 3. Dally searching effort and the densities of humpback whale groups seen from the lighthouse at Cape Columbine
The tracks of all 59 humpback whale groups for which at least 1 theodolite fix was obtained are shown in Fig 4. The tracks are more extensive to the north of the lighthouse than to the south, but this probably reflects (1) the influence of the setting sun in the afternoon (which effectively prevented tracking in a section to the southwest), and (2) the prevailing southerly direction of the wind, which hindered prolonged searching and tracking to the south.

The tracks also suggest an area of avoidance in a line between 3 and $6 \mathrm{~km}$ to the north of the lighthouse; this probably reflects the existence of individual rocks and blinders in the area.

Because of the conformation of the coast, with large bays either side of the point on which the lighthouse stood, there was a tendency for groups to pass closer to the coast when due west of the lighthouse than to the north or south. This means that calculations of the average distance offshore are likely to overestimate the distance at which groups are from the lighthouse when on the midline; just about all humpback groups, for instance, were within $4 \mathrm{~km}$ of the coast at this point (cf. Fig. 5)

\section{Visibility and the distance of sightings offshore}

In total, 346 hourly readings were made of meteorological visibility on the midline $\left(270^{\circ}\right)$ during periods of active watch, using the vertical index of the theodolite. Excluded from this total are readings taken in the late afternoon on sunny days, when the glare tended to give a spurious impression of visibility. Expressed as a cumulative frequency, the pattern of readings reveals a fairly rapid fall-off in visibility above $4 \mathrm{~km}$ from the shore, which flattens out again over $9 \mathrm{~km}$, with an apparent maximum limit to visibility of $21.5 \mathrm{~km}$ (Fig. 5). The median of all readings occurred at just over $7 \mathrm{~km}$ from the shore.

All 59 groups of humpback whales for which at least 1 accurate theodolite fix was obtained had average offshore distances of less than $8.5 \mathrm{~km}$ from the coastline (Fig. 5), with a peak at 2 to $2.5 \mathrm{~km}$ from the shore; the mean distance was $3.1 \pm 0.2 \mathrm{~km}$. This contrasts with the situation directly offshore of Cape Columbine, where virtually all humpback whales seen were within $4 \mathrm{~km}$ from the headland (Fig. 4).

There were 28 groups of whales for which at least 1 accurate theodolite fix was taken that could not be identified to species, although some were labelled 'like-humpback' and some 'like-right' ('like-minke' were excluded). Because part of the reason for their lack of identification could be their distance from the observers, their offshore distribution has been added to Fig. 5. These groups were seen up to $12-12.5 \mathrm{~km}$ 


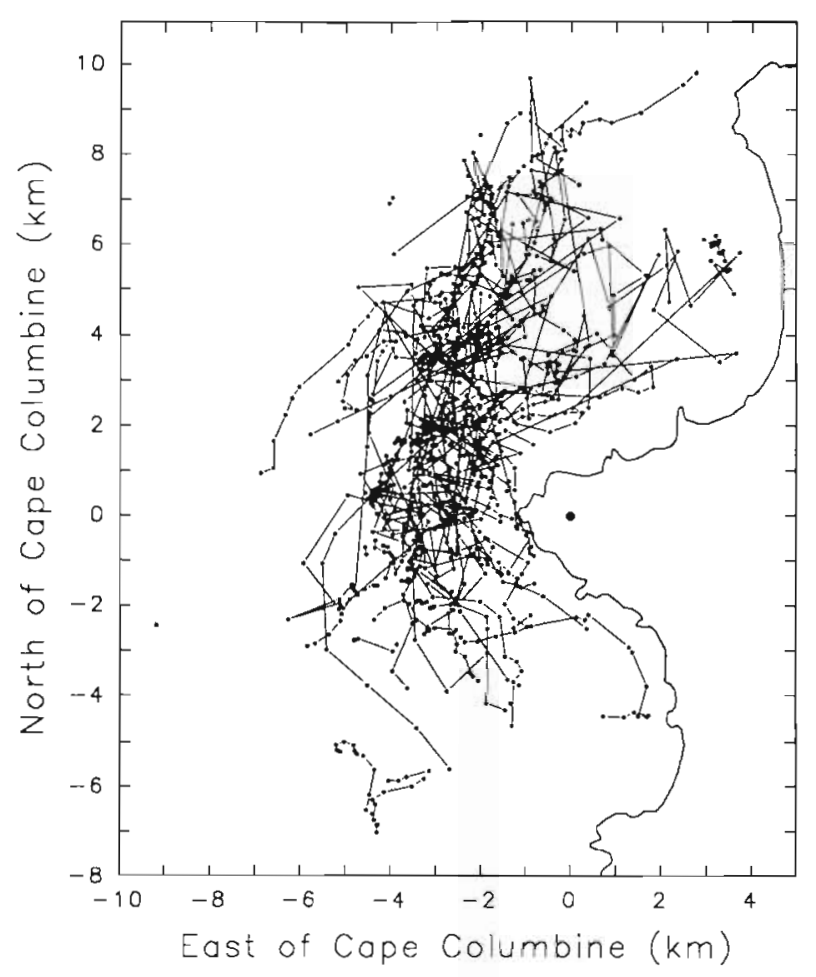

Fig. 4. Tracks of humpback whale groups as determined by theodolite from the lighthouse (solid circle) at Cape Columbine

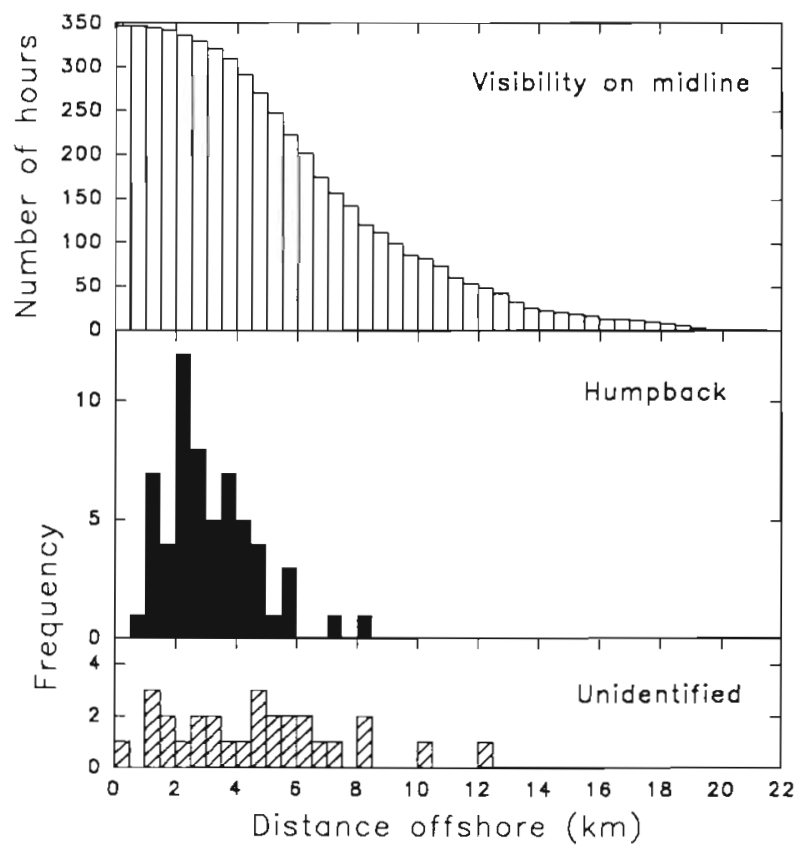

Fig. 5. Hourly visibility on the midline and average distances from the coast of groups of humpback and unidentified whales at Cape Columbine
Table 2. Numbers of humpback whales seen, and the searching effort by the ski-boat 'Ecklonia', in 4 distance strata from the coast in the vicinity of Cape Columbine, October-November 1993

\begin{tabular}{|lccccc|}
\hline & \multicolumn{8}{c|}{ Stratum (km from the coast) } \\
& $0-5$ & $5-10$ & $10-15$ & $15+$ & Total \\
\hline No. of groups/whales & $6 / 14$ & $2 / 4$ & 0 & 0 & $8 / 18$ \\
Effort (km searched) & 519 & 266 & 148 & 179 & 1112 \\
\hline
\end{tabular}

from the coast (average $4.7 \pm 0.5 \mathrm{~km}$ ), with no obvious peaks in distribution.

The patterns of offshore distribution shown in Fig. 5 could reflect either the fall-off in visibility with distance, or the real near-shore distribution of the species, or a combination of both. Independent data on offshore distribution are potentially available from sightings made on transects searched by the 'Ecklonia'. The total of $1112 \mathrm{~km}$ searched by the 'Ecklonia' between 12 October and 10 November has been divided into 4 strata $(0$ to 5,5 to 10,10 to 15 and $>15 \mathrm{~km}$ from the coast), and the numbers of humpback whales sighted in each stratum summed (Table 2).

Clearly fewer humpback whales were seen in the offshore than in the inshore strata, but because of the small numbers of whales seen from the boat only 2 strata can really be considered, 0 to 5 and $>5 \mathrm{~km}$ offshore. The null hypothesis that the density of humpbacks was equal in these 2 strata was rejected $\left(\chi^{2}=\right.$ $7.00,0.005<p<0.01$ ). In order to test an alternative hypothesis, that the proportions of humpback groups seen in these 2 strata from the lighthouse do not differ from the proportions that might be expected from the boat sightings, half the number of unidentified sightings from the lighthouse were added to the number of humpback sightings, on the basis that the more distant groups were less easy to identify, and that about half the groups of identified whales were humpbacks (Table 1). This alternative hypothesis also could not be rejected $\left(\chi^{2}=0.579,0.5>p>0.25\right)$.

\section{Group size and composition}

Because of the frequency with which groups split and merged in this study, 'group size' is a somewhat arbitrary parameter. Nevertheless, when first encountered by the 'Ecklonia', the 12 groups of humpbacks intercepted ranged in size from 1 to 5 with a mean of $2.3 \pm 0.3$ whales. These exclude a fin whale which frequently was in association.

Estimates of humpback whale group size made from the lighthouse were similar, ranging from 1 to 5 with a mean of $2.7 \pm 0.1$, but cannot be considered as 
reliable because of the distance at which they were made.

None of the 12 humpback whale groups intercepted by the 'Ecklonia' contained any obvious calves or juveniles. Calves were recorded from the lighthouse, however, on 5 occasions; 2 of these were on 7 October, 2 on 8 October and 1 on 12 November. Group sizes involved were $6,3,2,2$ and 3 respectively. However, considering that observers were a minimum of $1 \mathrm{~km}$ away from shore-based sightings, their ability to spot and correctly classify calves was probably seriously impaired and the apparently low incidence of calves should not be considered very significant.

\section{Direction of movement}

To reduce variability, directions of movement were only calculated for groups for which more than 2 accurate theodolite fixes were available. Net bearings for 51 humpback whale groups showed a virtually uniform distribution between 0 to $19^{\circ}$ and 340 to $359^{\circ}$ (Fig. 6). If these bearings are summed by compass quadrant $\left(315\right.$ to $45^{\circ}$, north; 45 to $135^{\circ}$, east; 135 to $225^{\circ}$, south; 225 to $315^{\circ}$, west), there is no significant difference in the numbers of groups showing net directions of movement to each quadrant $\left(\chi^{2}=1.7842,0.75>\right.$ $\mathrm{p}>0.50)$.

To determine whether there was any seasonal difference in net bearings, the data have been analysed sep-

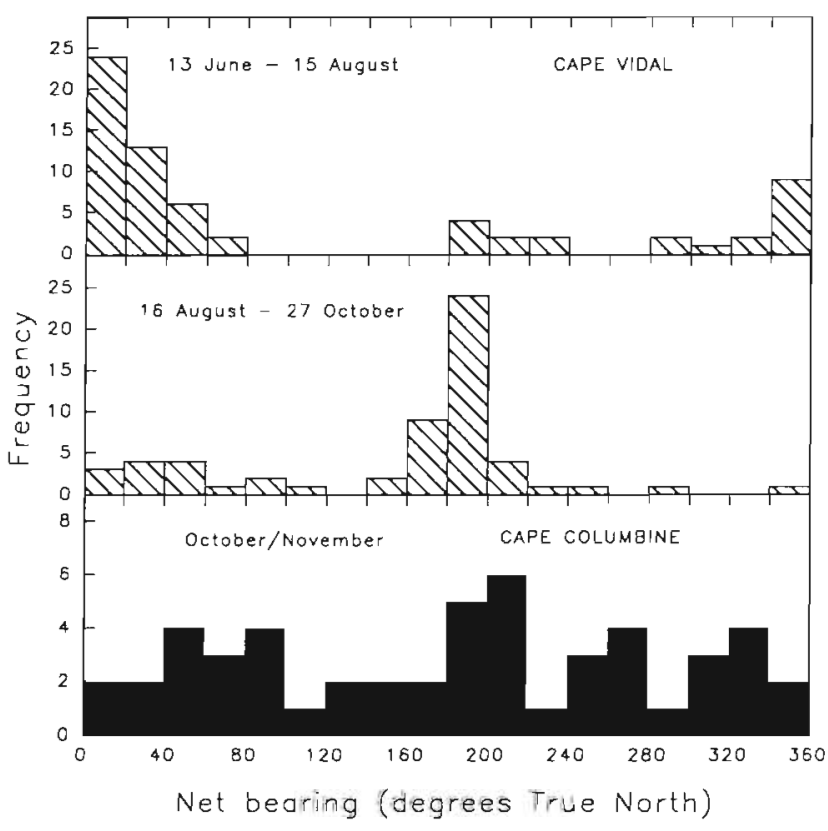

Fig. 6. Net bearings of groups of humpback whales tracked by theodolite from Cape Columbine (solid) and Cape Vidal (shaded) arately for the first ( 6 to 17 October) and subsequent (after 27 October) episodes of humpback whale density as determined from the lighthouse (number of groups $=30$ and 21 respectively). The distribution of net bearings summed by compass quadrant was not significantly different between the 2 time periods $\left(\chi^{2}=4.299\right.$. $0.25>\mathrm{p}>0.10$ ).

Also shown in Fig. 6 are the distributions of net bearings for humpback whale groups migrating past Cape Vidal in 1990. Two time periods are shown, 13 June to 15 August (corresponding to the timing of the northward migration) and 16 August to 27 October (corresponding to the timing of the southward migration). The distribution of net bearings by compass quadrant (shifted $15^{\circ}$ to the east to account for the more easterly alignment of the coast at Cape Vidal, i.e. 330 to $60^{\circ}$, 60 to $150^{\circ}, 150$ to $240^{\circ}, 240$ to $330^{\circ}$ ) was non-uniform in both periods $\left(\chi^{2}=111.7\right.$ and 58.8 respectively, $p<0.001$ in both).

As a measure of the purposefulness of movement for individual groups, the dispersion of headings around the average bearing was calculated from the length of the mean vector, $r$, and the uniformity of the distribution of headings shown by each group examined using Rayleigh's z-test (Zar 1984). In 19 of the 51 groups examined at Cape Columbine the null hypothesis of uniform distribution could be rejected (Fig. 7). Of these, 12 were headed in a general southerly direction $\left(90-180-270^{\circ}\right)$ and 7 in a general northerly direction $\left(270-360-90^{\circ}\right)$, proportions that are not significantly different from parity $\left(\chi^{2}=1.316,0.50>p>0.25\right)$. Consequently those groups that did seem to be moving in a particular direction were as often moving north as south.

Also shown in Fig. 7 are the distributions of average bearings for humpback whale groups at Cape Vidal for the 2 periods in 1990 that corresponded essentially to the northern and southern migrations. In both periods those groups with significant $z$-values (and thus showing a concerted direction of movement) were nonuniformly distributed between a northerly direction (285-360-105) and a southerly direction (105-180285), there being proportionally more headed in a northerly direction in the first period and more headed in a southerly direction in the second period $\left(\chi^{2}=11.27\right.$ and $6.25, \mathrm{p}<0.001$ and $<0.025$ respectively).

\section{Speed of movement}

As with the direction of movement, speeds were only calculated for groups for which more than 2 accurate fixes were available, to reduce variability. There were 51 groups of humpback whales for which sufficient data were available (Fig. 8). Average speeds, corresponding to the actual swimming speed of each group, 


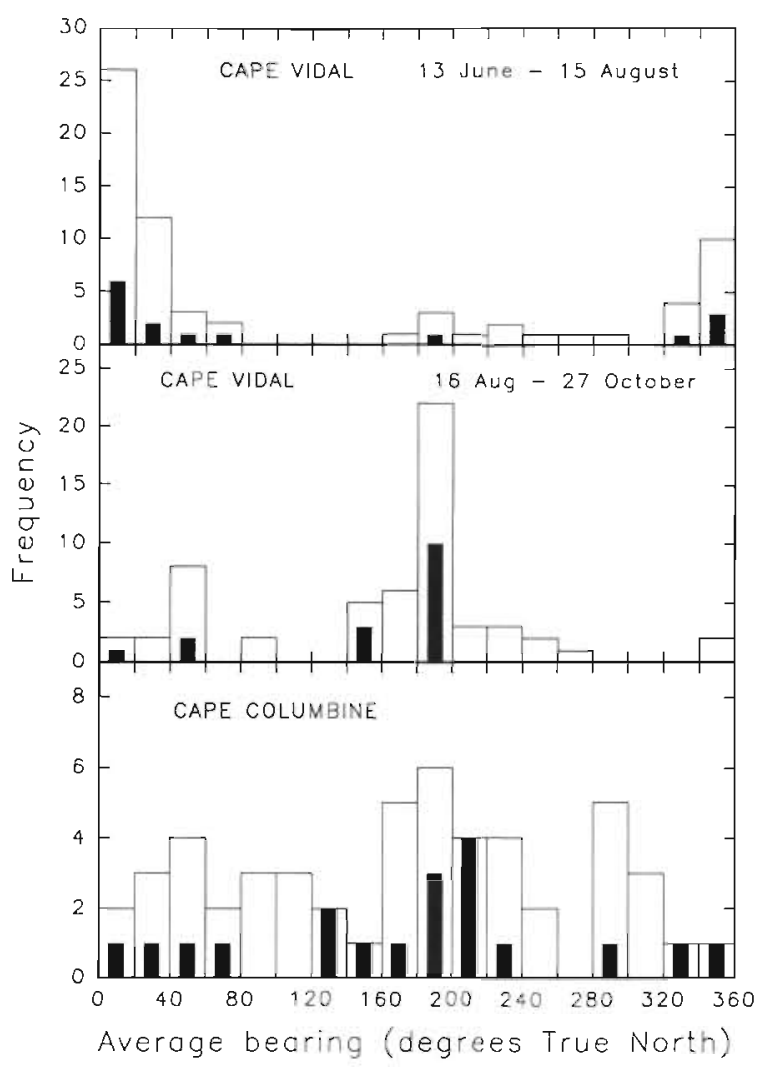

Fig. 7. Average bearings of groups of humpback whales (open), and those groups showing significant $z$-values (solid), tracked by theodolite from Cape Columbine and Cape Vidal

showed an approximately normal distribution, and ranged from 0.5 to 6 with a mean of $2.8 \pm 0.2 \mathrm{~km} \mathrm{~h}^{-1}$. The distribution of net speeds, however, was markedly skewed to lower values, with a mode at 0.25 to $0.49 \mathrm{~km}$ $\mathrm{h}^{-1}$. About $70 \%$ of groups travelled at net speeds of less than $1.5 \mathrm{~km} \mathrm{~h}^{-1}$, whereas about $90 \%$ of groups showed average speeds in excess of $1.5 \mathrm{~km} \mathrm{~h}^{-1}$.

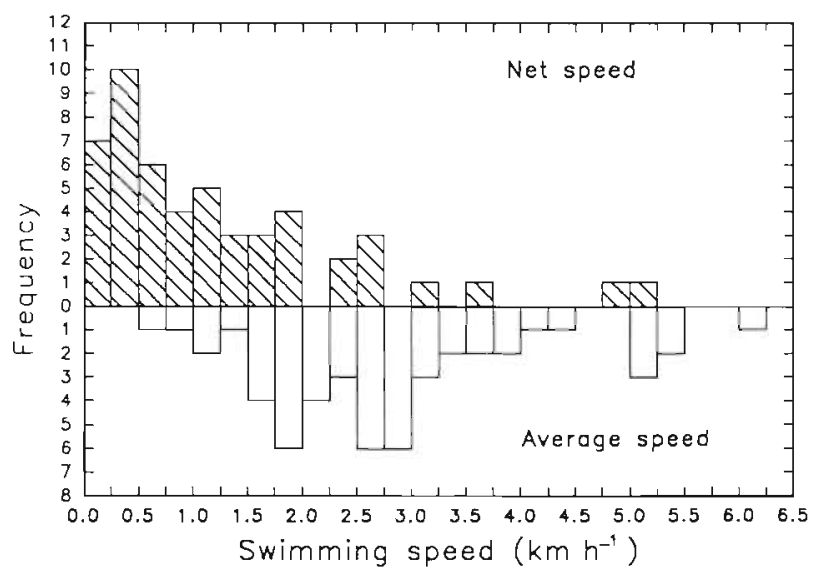

Fig. 8. Net (shaded) and average (unshaded) speeds of movement of groups of humpback whales tracked by theodolite from Cape Columbine
At Cape Vidal, net swimming speeds on the northern migration averaged annually from 3.6 to $5.4 \mathrm{~km} \mathrm{~h}^{-1}$ between 1988 and 1991, and on the southern migration in 1990 averaged $5.3 \mathrm{~km} \mathrm{~h}^{-1}$ (Findlay 1994).

As some measure of the purposefulness of movement of individual groups, a migratory index was calculated from the ratio of the average swimming speed to the net speed of movement. Thus if a group was moving continually in one direction, the index would be 1.0 , irrespective of the actual swimming speed; the more the group deviated from one direction, the greater the index would differ from 1.0. The distribution of these migratory indices is illustrated separately for groups showing a net movement to each of the 4 compass quadrants (Fig. 9).

Also shown in Fig. 9 is the distribution of migratory indices for 125 humpback whale groups observed at Cape Vidal between 13 June and 27 October 1990; 113 (or $90.4 \%$ ) of these had indices of less than 1.5. As the majority of whales seen off Cape Vidal were actively migrating, values of 1.0 to 1.49 could be taken as indicative of a migrating group.

On this assumption, only 15 or $29.4 \%$ of groups seen off Columbine would be classified as actively migrat-

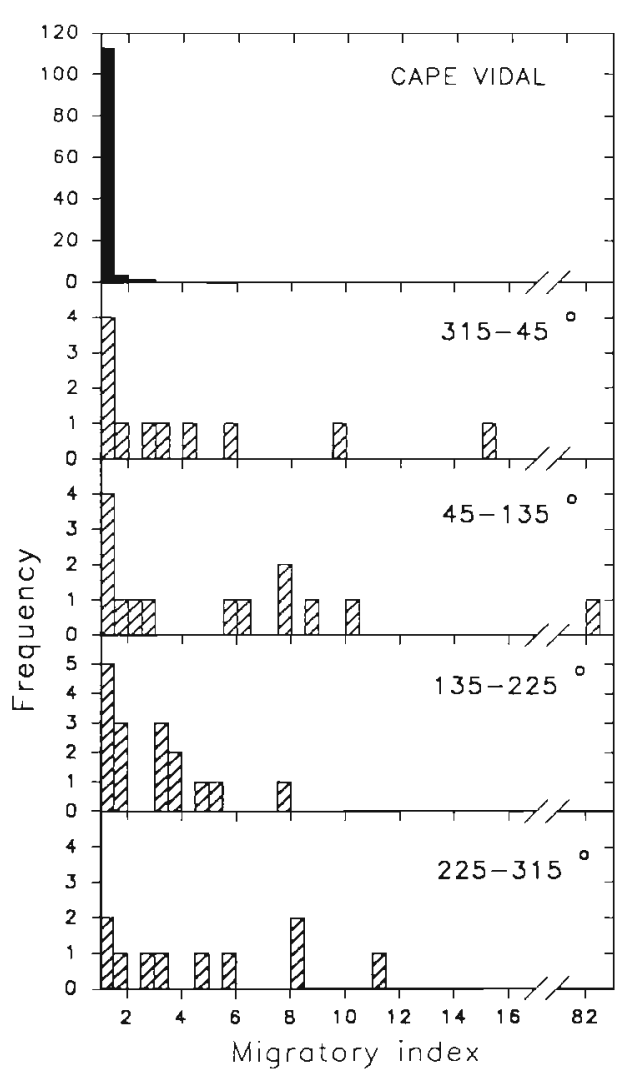

Fig. 9. Migratory indices for humpback whale groups at Cape Vidal (solid) and for groups at Cape Columbine travelling to 4 quadrants of the compass (hatched) 
Table 3. Resightings of individually identified humpback whales A to J off Cape Columbine, October-November 1993 ('whale present but unidentified)

\begin{tabular}{|c|c|c|c|c|}
\hline \multirow[t]{2}{*}{ Date } & \multirow{2}{*}{$\begin{array}{l}\text { Sighting } \\
\text { no. }\end{array}$} & \multicolumn{3}{|c|}{ Individual identified } \\
\hline & & Right dorsal & Left dorsal & Flukes \\
\hline 17 Oct & 1 & $A, B$ & $A, B$ & $A, B$ \\
\hline 17 Oct & 2 & C. D & C. D & $C, D$ \\
\hline 17 Oct & 4 & $A, B, C$ & $A, B, C$ & $\because \cdot C$ \\
\hline 25 Oct & 1 & $A, E$ & $A, E$ & $A_{1} \cdot$ \\
\hline 27 Oct & 1 & $F, G$ & $F, G$ & $F, G$ \\
\hline $27 \mathrm{Oct}$ & 3 & $\cdot \mathrm{H}$ & $\mathrm{C}, \mathrm{H}$ & $\cdot \mathrm{H}$ \\
\hline 28 Oct & 1 & $F, G$ & $F, G$ & $F, G$ \\
\hline 29 Oct & 1 & C,I & C.I & $\mathrm{C}, \cdot$ \\
\hline 29 Oct & 3 & $\cdot \cdot$ & $A_{1} \cdot$ & $A_{1} H$ \\
\hline $31 \mathrm{Oct}$ & 1 & $\cdot$ & $\mathrm{J}$ & $\cdot$ \\
\hline 31 Oct & 3 & $\begin{array}{c}A_{1}, C, F_{1} \\
G, H\end{array}$ & $\begin{array}{c}A_{1}, C_{1}, F_{1} \\
\text { G. H }\end{array}$ & $\begin{array}{l}{ }^{\prime} C_{1}, F_{1} \\
G_{1} H\end{array}$ \\
\hline $5 \mathrm{Nov}$ & 1 & $\Delta, H$ & $A, \underline{H}$ & $\cdot \mathrm{H}$ \\
\hline
\end{tabular}

ing. As 8 of these were heading in a northerly (270$\left.360-90^{\circ}\right)$ direction and 7 in a southerly $\left(90-180-270^{\circ}\right)$ direction, the null hypothesis that 'migrating' groups were heading equally in either direction cannot be rejected $\left(\chi^{2}=0.067,0.9>p>0.75\right)$

\section{Individual identification}

Twelve groups of 27 humpback whales were encountered by boat, of which 23 were identified from photographs of the right side of the dorsal fin, 26 from the left side of the dorsal fin and 19 from the ventral surface of the tail flukes. The total number of individuals involved, however, was only 10, of which 9 were identified from photographs of the left side of the dorsal fin, all 10 from photographs of the right side of the dorsal fin, and 7 from tail fluke pictures (Table 3).

Five of the individuals ('residents'?) were seen on more than $1 \mathrm{~d}$, over spans of 20 ( 1 ind.), 15 ( 1 ind.), 10 (1 ind.) and 5 ( 2 ind.) d. The other 5 individuals ('transients'?) were only seen once. As the first and last boat encounters with humpback whales were $20 \mathrm{~d}$ apart, these 'residency' times may well be underestimates.

Association between individuals was quite fluid. Each of the 5 'resident' whales was seen together with the other 'resident' individuals at least once, and all but one of the 'transient' individuals was seen in association with at least 1 'resident'

\section{Association with a fin whale}

On 8 October observers in the lighthouse noticed a whale associating with up to 6 humpback whales that was clearly a different species, and the shape of the dorsal fin (as viewed through the theodolite telescope) most closely resembled that of a fin whale. The whale was noticed again on 16 October, associating with up to 4 humpback whales, but it was only on 17 October, when the 'Ecklonia' was able to intercept the animal with a group of 2 humpback whales, that its identity could be confirmed as a fin whale. Subsequently the whale was seen on a further 5 occasions: on 28 October from both the boat and lighthouse, with 2 humpback whales, on 29 October from the lighthouse with 3 humpback whales, on 31 October from the boat with 5 humpback whales, and on 5 November from the boat with 2 humpback whales.

Besides fin shape, field characters used for species identification were (1) the single central ridge on the rostrum, (2) the shoulder chevron marking and (3) the pale right lower lip. The individual was also clearly recognisable from a set of tooth rakes on both sides ot the dorsal fin near the tip, seen on every occasion from the 'Ecklonia' (but of course undetectable from the lighthouse). Assuming that the same individual was involved in all the sightings, this whale was present in the area over a total period of $29 \mathrm{~d}$.

The fin whale was never spotted on its own, always in association with humpback whales (and never with right whales). On each occasion that it was encountered by the 'Ecklonia', the fin whale remained with humpback whales throughout the interception, even if the group split up. Association with individual humpbacks, however, was fluid; the fin whale was seen on 2 occasions with each of the 5 'resident' humpback whales, but only once with one of the 'transient' whales.

On 8 October the fin whale was seen from the lighthouse associating with a group of (apparently) feeding humpback whales, and a sample of its faeces collected from the 'Ecklonia' on another occasion confirmed that it was feeding in the area (see below).

\section{Feeding behaviour}

Humpback whales engaged in apparent feeding behaviour were observed on 10 occasions from the lighthouse, using the $30 \times$ magnification of the theodolite telescope (Table 4). Behaviours seen were exclusively of the 'lunge feeding' type (Jurasz \& Jurasz 1979), including surfacing vertically or horizontally with the mouth open, in both of which the 'bagged' ventral grooves could clearly be seen. Such feeding was only seen in groups of 3 or more (up to 6 or 8 ) individuals. Although its duration was not specifically recorded, on 1 occasion it lasted for at least 22 min. 
Table 4. Instances of apparent feeding by humpback whales observed from Cape Columbine, October/November 1993

\begin{tabular}{|ccccl|}
\hline Date & Group size & Time & $\begin{array}{c}\text { Distance offshore } \\
(\mathrm{km})\end{array}$ & \multicolumn{1}{c|}{ Description } \\
\hline 7 Oct & 3 & $18: 17 \mathrm{~h}$ & 2.3 & 2 side lunges, 3 surfacing vertically with open mouth \\
8 Oct & 3 & $10: 20 \mathrm{~h}$ & 0.9 & Sideways feeding \\
8 Oct & $6-8^{\mathrm{d}}$ & $12: 23 \mathrm{~h}$ & 1.4 & Surface feeding \\
& & $12: 30 \mathrm{~h}$ & 1.3 & \\
8 Oct & 4 & $16: 36 \mathrm{~h}$ & 1.7 & Stationary \\
8 Oct & 3 & $15: 37 \mathrm{~h}$ & 0.8 & Side lunges \\
& & $15: 59 \mathrm{~h}$ & 1.7 & \\
8 Oct & 4 & $17: 37 \mathrm{~h}$ & 3.1 & Sideways feeding \\
10 Oct & 3 & $08: 00 \mathrm{~h}$ & 2.9 & Surface feeding \\
11 Oct & 4 & $15: 48 \mathrm{~h}$ & 2.5 & Surface feeding? \\
27 Oct & 3 & $09: 56 \mathrm{~h}$ & 3.5 & Surfacing rostrum first \\
& & $10: 03 \mathrm{~h}$ & - & All 3 side-lunging, several surfacings vertically with mouth open \\
13 Nov & $3-4$ & $12: 09 \mathrm{~h}$ & 2.2 & Surfacing vertically with mouth open \\
& & $12: 19 \mathrm{~h}$ & 2.1 & Surfacing vertically with mouth open \\
ancludes single fin whale & &
\end{tabular}

Feeding took place between 0.8 and $3.5 \mathrm{~km}$ (average $2.2 \mathrm{~km}$ ) offshore, but this distinction may be influenced by the difficulty of making behavioural observations at greater distances.

The time at which apparent feeding was observed ranged from 08:00 to $18: 17 \mathrm{~h}$, with no obvious diurnal pattern; such behaviour was recorded during every hour between these times except from 11:00 to $12: 00 \mathrm{~h}$ and from 13:00 to 15:00 h.

Seabird activity around these feeding humpbacks was comparatively limited, with no indications of diving gannets or cormorants, and only a few terns present.

\section{Defecation rates}

During interceptions by the 'Ecklonia', groups of humpback whales (or humpbacks plus a fin whale) were seen to defecate on 7 occasions. These were invariably a bright reddish or terracotta colour, and produced as a stream of particulate matter rather than as a formed stool. On an eighth occasion, however, some apparent stools were found floating at the surface while a group of humpback whales was being followed, but the production of the stools was not observed. By contrast, these stools were a dark greenish colour.

As the times at which the 'Ecklonia' closed with and left each group were recorded, some calculation can be made of the rate of defecation of each group, ranging from 0 to 0.442 defecations whale ${ }^{-1} \mathrm{~h}^{-1}$, with a weighted average of 0.219 defecations whale ${ }^{-1} \mathrm{~h}^{-1}$
(Table 5). These values of course assume that every defecation was seen, whereas frequently the groups were submerged during long dives, or surfaced after such a dive at some distance from the boat, at which times whales could well have defecated undetected. On the other hand, disturbance caused by the boat's presence might have stimulated stool production.

There is some evidence, indeed, that the presence of the boat affected faeces production. No faeces were detected during interceptions lasting less than $1 \mathrm{~h}$ ( $\mathrm{n}=$ 5), whereas the defecation rate in longer interceptions averaged 0.273 whale $^{-1} h^{-1}(n=7)$.

\section{Faecal analysis}

Four samples of faeces were collected. Three of these were from streams of reddish particulate matter produced by humpback whales (2) or the fin whale (1), while the fourth was from the dark greenish floating stools not attributed to any whale. After rinsing through a $10 \mu \mathrm{m}$ filter the latter contained no identifiable prey material, and the colour and consistency suggested a largely mucus mass stained with bile production, perhaps representing a stool from an individual that had not fed for some time.

Two of the other samples (1 from the fin and 1 from a humpback whale) contained Euphausia mandibles, not identifiable to species. However, given the collection location (close inshore on the west coast), and the fact that the euphausiids were probably swarming, the most likely candidate would be E. lucens (M. J. Gibbons pers. comm.) 
Table 5. Instances of defecation and estimated defecation rates for humpback whales (and 1 fin whale) off Cape Columbine, October-November 1993

\begin{tabular}{|c|c|c|c|c|c|}
\hline \multirow[t]{2}{*}{ Date } & \multicolumn{2}{|c|}{ No. of whales } & \multirow[t]{2}{*}{ Time (h) } & \multirow{2}{*}{$\begin{array}{l}\text { Number of } \\
\text { defecations }\end{array}$} & \multirow{2}{*}{$\begin{array}{l}\text { Defecation rate } \\
\text { (no. whale }{ }^{-1} \mathrm{~h}^{-1} \text { ) }\end{array}$} \\
\hline & Humpback & Fin & & & \\
\hline $17 \mathrm{Oct}$ & 2 & 0 & 1.63 & 0 & 0 \\
\hline $17 \mathrm{Oct}$ & 2 & 1 & 1.43 & 2 & 0.466 \\
\hline 17 Oct & 3 & 0 & 0.35 & 0 & 0 \\
\hline $25 \mathrm{Oct}$ & 2 & 0 & 0.78 & 0 & 0 \\
\hline $27 \mathrm{Oct}$ & 2 & 0 & 1.26 & 0 & 0 \\
\hline $27 \mathrm{Oct}$ & 2 & 0 & 1.50 & $0^{a}$ & 0 \\
\hline $28 \mathrm{Oct}$ & 2 & 1 & 0.62 & 0 & 0 \\
\hline $29 \mathrm{Oct}$ & 2 & 0 & 0.67 & 0 & 0 \\
\hline $29 \mathrm{Oct}$ & 2 & 0 & 1.13 & 1 & 0.442 \\
\hline 31 Oct & 1 & 0 & 0.48 & 0 & 0 \\
\hline $31 \mathrm{Oct}$ & $5^{b}$ & 1 & 2.33 & 3 & 0.429 \\
\hline 5 Nov & 2 & 1 & 1.10 & 1 & 0.303 \\
\hline Total & 27 & 4 & 13.28 & 7 & 0.219 \\
\hline
\end{tabular}

The fourth sample (from a humpback whale), unlike the previous 2 which were collected using a 1 I plastic bottle, was gathered using a dip net made of plankton netting, which observation showed was of too coarse a mesh to retain most of the particulate matter. Hence the identifiable prey remains (bits of the amphipod Themisto (presumably gaudichaudi) and an unidentified ostracod) may not be representative of the faeces in this instance.

\section{DISCUSSION}

Although the pattern of daily densities of humpback whales seen at Cape Columbine in October/November 1993 was reminiscent of the 'waves' of humpbacks recorded passing Cape Vidal on their northern migration (Findlay 1994), other parameters contradicted the impression that this was a migration. Firstly, there was no dominant direction of movement, the net bearings of groups being recorded equally to all 4 quadrants of the compass. This contrasted markedly with the situation at Cape Vidal, where on both northern and southern migrations there was a distinct peak in net movement around bearings that lay parallel with the coast. Secondly, those groups which did appear to show a concerted directionality of movement were as often moving north as south. Thirdly, the modal net speed of movement was an order of magnitude slower than the average at Cape Vidal on either northern or southern migrations (Findlay 1994). Even the mean average speed of movement $\left(2.8 \mathrm{~km} \mathrm{~h}^{-1}\right)$ was much slower than the net rate of movement recorded at Cape Vidal, or on the West Australian coast, where it averaged 7.4 and
$9.2 \mathrm{~km} \mathrm{~h}^{-1}$ for adults with and without calves respectively (Chittleborough 1953). It was comparable, however, to the net speed of migration calculated by Dawbin (1956) from the timing of migration peaks off New Zealand $\left(2.4 \mathrm{~km} \mathrm{~h}^{-1}\right)$. Fourthly, the migratory indices for individual groups showed that even those whose net speed approached their average speed were moving equally in a northerly and southerly direction. And lastly, the occurrence of photographically identified whales indicated that some individuals were semi-resident in the area, being resighted as much as $20 \mathrm{~d}$ after being first seen.

The finding of an apparently non-migratory population of humpback whales in spring off the South African west coast was unexpected. Humpback whales 'dawdling' on migration have been recorded earlier. Chittleborough (1965), for instance, refers to a whale marked on 30 July close to Norfolk Island and killed in the same locality 10 d later, while Dawbin (1966) refers to others marked at Fiji and in Cook Strait, New Zealand, that were recaptured or observed 3 to $9 \mathrm{~d}$ Iater close to the position of marking, having made no significant progress north in that time. Dawbin (1956) also recorded 2 humpbacks (individually recognisable from a protruding whale mark and a distinctive colour pattern) that remained in the Foveaux Strait region of New Zealand for 2 and 4 d respectively in November. While not as specific, Olsen (1914) referred to an anomalous southern migration of humpback whales off both coasts of South Africa in 1.91.2, when whales were very restless and shy, and instead of moving continually south, moved back and forth along the coast for a long time. Nevertheless, the Cape Columbine observations seem to be the first occasion on which a number 
of individuals has been documented as essentially ceasing migration, and certainly for the longest period (some at least for $20 \mathrm{~d}$ ).

It seems likely that the unusual migratory behaviour of the whales was related to the presence of food and the incidence of feeding. According to Dawbin (1956), humpbacks on the New Zealand coast do feed in certain areas during their southward migration, and at times deviate towards local concentrations of food or linger for a period before continuing south. Cape Columbine is well known as an upwelling area, with possible maxima in the uplift of near-surface water in October-November and March-April (Shannon 1985). During the summer months, very high concentrations of Euphausia lucens (10000 and over in a haul) have been found at stations within $18 \mathrm{~km}$ of the coast in the vicinity of the Columbine headland (Nepgen 1957), and swarms of the species close to the headland were also illustrated by De Decker (1973). The incidence of feeding behaviour (10 observations over $37 \mathrm{~d}$ ), the use of lunge feeding, which occurs when feed is abundant (Jurasz \& Jurasz 1979), and the frequent production (once every $5 \mathrm{~h}$ ) of reddish, particulate faeces suggests that the whales were actively exploiting this feeding opportunity. Previous quantitative information on humpback whale feeding on the west coast of South Africa is confined to the recording of 'fish' (1 identified as '?Clupeoids') in 2 out of 4 stomachs (Matthews 1938) and no food in a further 4 stomachs examined at Saldanha Bay (Best 1967). In addition, Olsen (1914) illustrates a stomach full of herrings ('sild') from the same locality and Findlay (1994) documents a calf entangled in a crayfish trap line outside Saldanha Bay in December as having fed on stomatopods.

In a review of humpback whale migrations off New Zealand, Dawbin (1956) described a number of observations which did not fit into the 'normal' migration pattern, specifically sightings off the New Zealand coast in January, February and March, of which some occurred regularly in the same area for several years in succession. Each of these sightings was associated with local concentrations of food organisms. He concluded that some humpbacks might remain for relatively long periods in such areas and possibly even fail to migrate to Antarctic waters. Chittleborough (1965) also reported sightings off Australia in November and December, but attributed these to exceptionally late southern (or early northern) migrations.

On the west coast of South Africa, Olsen (1914) reported that single young males, probably calves from the previous year, could be found throughout the summer outside Saldanha Bay, although most migrated south at this time of year. Findlay (1994) reported recent incidental sightings of humpback whales off the southwestern Cape coast in December,
January and February, and documents 2 mortalities of juvenile humpbacks in the area, 1 in December (entangled in a crayfish trap-line) and 1 stranded in February. While there is no evidence to link the Columbine observations with possible summer residence in the area, the region is inter alia the centre of a major purse-seine fishery for anchovy, pilchards and maasbanker (Crawford et al. 1987). Sightings of 'a great many' humpback whales at Hollams Bird Island, Namibia (24 $38^{\prime} \mathrm{S}$ ) in January 1829 were recorded by Best \& Shaughnessy (1979), and most of the nineteenth-century catches of humpback whales at Walvis Bay, Namibia ( $23^{\circ}$ S) occurred in October, November and January, as illustrated by Townsend (1935). It seems quite possible that the attractions of the high biological productivity afforded by the Benguela system in summer are sufficient to suspend or even prevent the southward migration of humpback whales to higher latitudes.

Acknowledgements. This work would not have been possible without the enthusiastic field assistance of Andre la Cock, Gabby Luyt, Michael A. Meyer, Anton Rossouw, Kerry Sink and Paul Zammit, to all of whom we are greatly indebted. Vince Calder, Rick Harding, Alan Kemp and Deon Kotze of the Sea Fisheries Research Institute were willing and able skippers of the 'Ecklonia' at any time and in almost any weather Logistic support at the Columbine lighthouse was generously provided by Portnet, and Brian Connolly and Eddie Crafford made us feel very much at home. Mark Gibbons of the Sea Fishenes Research Institute kindly identified bits and pieces that had been through several whales. Sue Binedell of the Department of Surveying. University of Cape Town, provided us with a digitised section of the coastline around Cape Columbine. This work was financially supported by a grant from the International Whaling Commission, for which we are extremely grateful, and P.B.B. acknowledges the support of the South African Marine Corporation Ltd, the Southern African Nature Foundation and the Foundation of Research Development.

\section{LITERATURE CITED}

Best, P. B. (1967). Distribution and feeding habits of baleen whales off the Cape Province. Investl Rep. Div. Sea Fish. S. Afr. 57: 1-44

Best, P. B. (1993). Increase rates in severely depleted stocks of baleen whales. ICES J. mar. Sci. 50: 169-186

Best, P. B., Shaughnessy, P. D. (1979). An independent account of Captain Benjamin Morrell's sealing voyage to the south-west coast of Africa in the Antarctic, 1828/29. Fish. Bull. S. Afr. 12:1-19

Bryden, M. M. (1985). Studies of humpback whales (Megaptera novaeangliae), Area V. In: Ling, J. K., Bryden, M. M. (eds.) Studies of sea mammals in south latitudes South Australian Museum, Adelaide, p. 115-123

Chittleborough, R. G. (1953). Aerial observations on the humpback whale, Megaptera nodosa (Bonnaterre), with notes on other species. Aust. J. mar. Freshwat. Res. 4: $219-226$

Chittleborough, R. G. (1965). Dynamics of two populations of 
the humpback whale. Megaptera novaeangliae (Borowski). Aust. J. mar. Freshwat. Res. 16: 33-128

Crawford, R. J. M., Shannon, L. V., Pollock, D. E. (1987). The Benguela ecosystem. Part IV. The major fish and invertebrate resources. Oceanogr mar Biol. A. Rev. 25: 353-505

Dawbin, W. H. (1956). The migrations of humpback whales which pass the New Zealand coast. Trans. R. Soc. N.Z. 84 (1): $147-196$

Dawbin, W. H. (1966). The seasonal migratory cycle of humpback whales. In: Norris, K. S. (ed.) Whales, dolphins and porpoises. University of California Press, Berkeley, p. $145-170$

De Decker, A. (1973). Agulhas Bank plankton. In: Zeitzschel, B. (ed.) Ecological studies. Analysis and synthesis. Vol. 3. Springer-Verlag, Berlin, p. 189-219

Findlay, K. P. (1994). The migrations of east coast humpback whales (Megaptera novaeangliae). Ph.D. thesis, University of Pretoria

This article was submitted to the editor
Jurasz, C. M., Jurasz, V. P. (1979). Feeding modes of the humpback whale, Megaptera novaeangliae, in southeast Alaska. Scient. Rep. Whales Res. Inst., Tokyo 31: 69-83

Kahmen, H., Faig, W. (1988). Surveying. W. de Gruyter, Berlin

Matthews, L. H. (1938). The humpback whale, Megaptera nodosa. 'Discovery' Rep. 17: 7-92

Nepgen, C. S. de V. (1957). The euphausilds of the west coast of South Africa. Investl Rep. Div. Fish. Un. S. Afr. 28: 1-30

Olsen, O. (1914). Hvaler og hvalfangst i Sydafrika. Bergens Mus. Aarbok Naturvitensk. Rekke 1914-15 (5): 1-56

Shannon, L. V. (1985). The Benguela ecosystem. Part I. Evolution of the Benguela, physical features and processes. Oceanogr. mar. Biol. A. Rev. 23: 105-182

Townsend, C. H. (1935). The distribution of certain whales as shown by logbook records of American whaleships. Zoologica (NY) 19(1): 1-50

Zar, J. H. (1984). Biostatistical analysis. Prentice-Hall, Inc., Englewood Cliffs, $\mathrm{NJ}$

Manuscript first received: June 21, 1994

Revised version accepted: November 22, 1994 